\title{
Chemical properties of a Haplustalf soil under irrigation with treated wastewater and nitrogen fertilization
}

\author{
Leda V. B. D. Silva ${ }^{1}$, Vera L. A. de Lima ${ }^{1}$, Howard W. Pearson ${ }^{2}$, \\ Tainara T. S. Silva ${ }^{1}$, Cris L. Maciel S. ${ }^{1} \&$ Valdinei Sofiatti ${ }^{3}$ \\ ${ }^{1}$ Universidade Federal de Campina Grande/Centro de Tecnologia e Recursos Naturais/Unidade Acadêmica de Engenharia Agrícola. Campina Grande, \\ PB. E-mail: ledavdantas@yahoo.com.br (Corresponding author); antuneslima@gmail.com; tainara.eng.agri@gmail.com; cris-lainny@hotmail.com \\ ${ }^{2}$ Universidade Federal de Campina Grande/Centro de Ciências e Tecnologia/Unidade Acadêmica de Engenharia Química. Campina Grande, PB. E-mail: \\ howard_william@uol.com.br \\ ${ }^{3}$ Empresa Brasileira de Pesquisa Agropecuária/Embrapa Algodão. Campina Grande, PB. E-mail: valdinei.sofiatti@embrapa.br
}

Key words:

reuse

soil fertility

irrigation

\begin{abstract}
A B S T R A C T
The objective of this research was to investigate the effects of irrigation with treated wastewater and nitrogen $(\mathrm{N})$ fertilization on the chemical characteristics of a Haplustalf soil cultivated with cotton. An experiment was conducted in a greenhouse in a completely randomized design with four replicates, and arranged in a $5 \times 4$ factorial. Five doses of $\mathrm{N}$ fertilization $\left(0,45,90,135\right.$ and $\left.180 \mathrm{~kg} \mathrm{ha}^{-1}\right)$ and four sources of irrigation water (freshwater, wastewater treated by an anaerobic reactor, wastewater treated by an anaerobic reactor and post-treated by intermittent sand filter in series, wastewater treated in a septic tank and post-treated by an intermittent sand filter) were tested. Irrigation was daily performed from July 2011 to January 2012 according to the water demand of cotton resulting in a water depth of $620 \mathrm{~mm}$. It was found that, compared with the conventional management with freshwater irrigation, treated wastewater provides greater accumulation of micronutrient, potassium and sodium in the soil, increasing the risk of sodification in irrigated areas.
\end{abstract}

\section{Palavras-chave:}

reúso

fertilidade do solo irrigação

\section{Atributos químicos de um Luvissolo Crômico sob irrigação com águas residuárias tratadas e adubação nitrogenada}

\footnotetext{
R E S U M O

Objetivou-se, nesta pesquisa, estudar os efeitos da irrigação com esgotos tratados e da adubação nitrogenada nos atributos químicos de um Luvissolo Crômico cultivado com algodoeiro herbáceo. Instalou-se um experimento em ambiente protegido, disposto em delineamento inteiramente casualizado com quatro repetições, em esquema fatorial $5 \times 4$. Foram testados cinco doses de adubação nitrogenada (0, 45, 90, 135 e $\left.180 \mathrm{~kg} \mathrm{ha}^{-1}\right)$ associadas a quatro fontes de água de irrigação (água do sistema de abastecimento público, efluente de esgoto tratado em reator anaeróbio, efluente tratado em reator anaeróbio e pós-tratado em filtros de areia intermitentes em série e efluente tratado em tanque séptico e pós-tratado em filtro de areia intermitente). Procedeu-se à irrigação diária de julho de 2011 a janeiro de 2012 com base na demanda hídrica da cultura do algodoeiro, com lâmina total de 620 $\mathrm{mm}$. Constatou-se, em relação ao manejo convencional com água de abastecimento, que a irrigação com esgotos tratados proporciona maior acúmulo de micronutrientes, potássio e sódio no solo, elevando os riscos de sodificação em áreas irrigadas.
} 


\section{INTRODUCTION}

Arid and semiarid regions are characterized by their high evaporation rates, where rainfall exceeds in most part of the year. In these regions, the practice of irrigation which is used to reduce the water deficit for crops, can increase the chances of success in agriculture and allow obtaining higher agricultural yields. On the other hand, one of the main social and environmental problems in semiarid areas is the scarcity of freshwater, which will probably be intensified in the next years due to not only high population growth rates, but also the increase in water demand for the agricultural sector (Bedbabis et al., 2014).

The application of treated domestic wastewater in the soil-plant system is, therefore, an attractive alternative, which allows increasing the available water supply and leverage the agricultural development of drought-affected areas. This practice is also beneficial from the environmental point of view, since, for using the soil as a natural filter, it reduces the negative impacts of the excessive discharge of nutrients and contaminants caused by the disposal of these effluents in surface waters (Bame et al., 2014).

Studies worldwide have proven the efficiency of municipal sewage effluents at substituting irrigation water for different agricultural crops. Great emphasis has been given to the reuse of organic and inorganic nutrients present in wastewaters for the fertilization of crops, which has allowed partially substituting, or even eliminating, the need for conventional fertilization. Many reports in the literature associate the practice of agricultural reuse with increments in crop yields (Leal et al., 2009a), adequate plant nutrition (Bedbabis et al., 2010) and beneficial alterations in soil physical-chemical characteristics, such as increase in fertility (Gwenzi \& Munondo, 2008; Bame et al., 2014), reduction of acidity (Leal et al., 2009b; Tarchouna et al., 2010), increment in the contents of organic matter (Rusan et al., 2007; Xu et al., 2010) and improvement in particle aggregation.

The use of wastewater can also result in negative effects, such as the increase in soil salinity, alteration of $\mathrm{pH}$ to undesirable values, creation of anaerobic conditions in the root zone and accumulation or excessive leaching of nutrients and heavy metals (Arienzo et al., 2009).

Continuous application of sewage effluents through irrigation is also capable of increasing the contents of exchangeable sodium in the soil exchange complex, to the detriment of exchangeable calcium, magnesium and potassium, generating problems of salinity and sodicity with negative impacts on soil structure and water absorption capacity (Lado \& Ben-Hur, 2009; Muyen et al., 2011). Additionally, some micronutrients potentially harmful to the development of sensitive plant species, such as boron and heavy metals, can be found in sewage effluents, and their progressive accumulation in the soil may make agriculture unviable. Therefore, before planning long-term wastewater irrigation, it is of prime importance to evaluate the probable effects of wastewater irrigation on soil degradation.

Wastewater effects on the soil depend, however, on a series of factors, such as the source and quality of the sewage effluents, crops to be irrigated and soil characteristics. Positive and negative impacts of irrigation with sewage effluents must be evaluated case by case, always associated with the type of soil irrigated and the planned management for the area.

This study aimed to evaluate the effects of irrigation with treated domestic wastewater and $\mathrm{N}$ fertilization on the chemical attributes of a Haplustalf cultivated with upland cotton.

\section{Material AND Methods}

The experiment was conducted in polyethylene pots maintained in a non-air-conditioned, arched-roof plastic greenhouse, with ceiling height of $2.5 \mathrm{~m}$ on the sides and $3.5 \mathrm{~m}$ in the central part, and open sides to maintain natural ventilation. The structure was installed in an area belonging to the Company of Water and Sewage of the Paraíba State (CAGEPA), located in the municipality of Campina GrandePB, Brazil (70 13' 11" S; 35 52' 31" W; $550 \mathrm{~m}$ ).

The experimental design was completely randomized with four replicates and the treatments were arranged in a $5 \times 4$ factorial scheme. The factors consisted of five nitrogen $(\mathrm{N})$ doses in the soil $\left(0,45,90,135\right.$ and $\left.180 \mathrm{~kg} \mathrm{ha}^{-1}\right)$, equivalent to $0,50,100,150$ and $200 \%$ of the $\mathrm{N}$ doses recommended for the irrigated cotton crop in the region (Cavalcanti, 2008), and four quality types of irrigation water: freshwater, from the public water supply system (FW); wastewater treated in upflow anaerobic sludge blanket (UASB) reactor; wastewater treated in UASB reactor and post-treated in two 0.5 -m-deep intermittent sand filters in series (UASB+ISF); wastewater treated in septic tank and post-treated in 1-m-deep intermittent sand filter (TS+ISF).

The chemical characterization of the effluents used for irrigation and the directions for the interpretation of irrigation water quality (Pescod, 1992) are shown in Table 1.

The pots were filled with soil classified as Haplustalf from the municipality of Alagoa Grande, PB, collected in the 0-40 $\mathrm{cm}$ soil layer in a rural settlement area with the following geographic coordinates: $7^{\circ} 04^{\prime} 60^{\prime \prime} \mathrm{S}$ and $35^{\circ} 37^{\prime} 50^{\prime \prime} \mathrm{W}$, at $140 \mathrm{~m}$ of altitude. The area of collection is reminiscent of the cotton expansion period in the state of Paraíba and has been maintained under fallow for approximately 15 years. After collection, the soil was pounded to break up clods, passed through a 2-mm-mesh sieve and placed in pots with capacity for $45 \mathrm{~L}$, above a layer of crushed stone of approximately 5 $\mathrm{cm}$ of thickness, put at the bottom of the pots in order to facilitate the drainage of irrigation water. One soil sample was collected for chemical characterization (Table 2).

The soil has alkaline reaction with very high $\mathrm{pH}$ and extremely low levels of potential $\left(\mathrm{H}^{+}+\mathrm{Al}^{3+}\right)$ and exchangeable $\left(\mathrm{Al}^{3+}\right)$ acidity, average content of organic matter and very good levels of phosphorus, potassium, calcium and magnesium (Alvarez V. et al., 1999). The soil is normal with respect to the level of salts and non-sodic in relation to the sodium saturation percentage (Ribeiro, 2010).

Upland cotton plants, cultivar BRS 286, were cultivated in pots under irrigation during one crop cycle, from July 2011 to January 2012. Planting was performed using six cotton seeds, with later thinning 15 days after emergence, leaving only one plant per pot, which was maintained until the end of the cycle. 
Table 1. Chemical characteristics of freshwater and wastewaters used for irrigation

\begin{tabular}{|c|c|c|c|c|c|}
\hline & FW & UASB & UASB + ISF & TS + ISF & $\begin{array}{c}\text { Threshold levels for } \\
\text { irrigation }^{\mathrm{a}}\end{array}$ \\
\hline $\mathrm{pH}$ & $7.13 \pm 0.61$ & $7.55 \pm 0.53$ & $7.00 \pm 0.41$ & $6.74 \pm 0.78$ & $6.5-8.4$ \\
\hline COD & ne & $169 \pm 21$ & $36 \pm 12$ & $51 \pm 7.9$ & - \\
\hline N-Total & ne & 89 & 69 & 46 & - \\
\hline $\mathrm{N}-\mathrm{NH}_{4}$ & ne & $82 \pm 4$ & $14 \pm 2$ & $5 \pm 2$ & - \\
\hline $\mathrm{N}-\mathrm{NO}_{3}$ & ne & $0.31 \pm 0.38$ & $34 \pm 2$ & $36 \pm 7$ & $<30$ \\
\hline P-Total & ne & $4.3 \pm 0.06$ & $0.8 \pm 0.1$ & $3 \pm 0.5$ & $<2$ \\
\hline $\mathrm{EC}\left(\mathrm{dS} \mathrm{m}^{-1}\right)$ & $0.78 \pm 0.17$ & $1.66 \pm 0.24$ & $1.22 \pm 0.63$ & $1.41 \pm 0.07$ & $0-3$ \\
\hline Calcium (mg L-1) & $33.16 \pm 6.33$ & $34.52 \pm 6.87$ & $43.52 \pm 8.65$ & $40.95 \pm 7.39$ & $<400$ \\
\hline Magnesium (mg L-1) & $26.58 \pm 3.96$ & $44.54 \pm 9.07$ & $34.05 \pm 4.34$ & $38.06 \pm 1.53$ & $<61$ \\
\hline Sodium $\left(\mathrm{mg} \mathrm{L}^{-1}\right)$ & $76.25 \pm 3.61$ & $157.21 \pm 11.21$ & $163.01 \pm 9.98$ & $148.43 \pm 7.39$ & $0-69$ \\
\hline Potassium (mg L-1) & $5.32 \pm 1.02$ & $21.66 \pm 0.65$ & $20.25 \pm 2.63$ & $21.11 \pm 0.55$ & $<2$ \\
\hline $\mathrm{SAR}^{\star}\left(\mathrm{mmolL}^{-1}\right)^{0.5}$ & $2.39 \pm 0.18$ & $4.16 \pm 0.30$ & $4.49 \pm 0.23$ & $4.01 \pm 0.31$ & $<9$ \\
\hline Sulfates (mg L-1) & absent & present & present & present & $<960$ \\
\hline Bicarbonates (mg L-1) & $116.39 \pm 21.65$ & $436.76 \pm 97.96$ & $107.85 \pm 43.39$ & $111.17 \pm 50.70$ & $<610$ \\
\hline Chlorides $\left(\mathrm{mg} \mathrm{L}^{-1}\right)$ & $176.28 \pm 2.53$ & $286.36 \pm 11.21$ & $265.52 \pm 5.41$ & $262.42 \pm 8.98$ & $<350$ \\
\hline Boron (mg L-1) & $0.24 \pm 0.01$ & $0.26 \pm 0.10$ & $0.35 \pm 0.07$ & $0.17 \pm 0.03$ & $<0.70$ \\
\hline Copper (mg L-1) & $<0.05$ & $<0.05$ & $<0.05$ & $<0.05$ & 0.20 \\
\hline Iron $\left(\mathrm{mg} \mathrm{L}^{-1}\right)$ & $<0.05$ & $0.46 \pm 0.06$ & $<0.05$ & $0.09 \pm 0.01$ & 5 \\
\hline Manganese (mg L-1) & $<0.03$ & $0.05 \pm 0.01$ & $<0.03$ & $<0.03$ & 0.20 \\
\hline $\operatorname{Zinc}\left(\mathrm{mg} \mathrm{L}^{-1}\right)$ & $<0.05$ & $<0.05$ & $<0.05$ & $<0.05$ & 2 \\
\hline
\end{tabular}

FW - Frashwater from the municipal supply system; UASB - Domestic wastewater treated in UASB reactor; UASB + ISF - Domestic wastewater treated in UASB reactor and post-treated in intermittent sand filters; TS + ISF - Domestic wastewater treated in septic tank and post-treated in intermittent sand filter; ne - Not evaluated; COD - Chemical oxygen demand; N-Total - Total nitrogen; $\mathrm{N}-\mathrm{NH}_{4}$ - Ammoniacal nitrogen; $\mathrm{N}-\mathrm{NO}_{3}$ - Nitrate; $\mathrm{P}$-Total - Total phosphorus; ${ }^{*} \mathrm{SAR}$ - Sodium adsorption rate: $[\mathrm{Na} /(\mathrm{Ca}+\mathrm{Mg}) / 2]^{0.5}$; aThreshold levels of elements in waters intended for irrigation (Pescod, 1992)

Table 2. Characteristics of the Haplustalf used in the experiment

\begin{tabular}{lc}
\hline \multicolumn{1}{c}{ Treatment } & Value \\
\hline $\mathrm{pH}$ in water & 7.2 \\
$\mathrm{EC}\left(\mathrm{dS} \mathrm{m}^{-1}\right)$ & 0.34 \\
$\mathrm{OM}\left(\mathrm{g} \mathrm{kg}^{-1}\right)^{1}$ & 23.4 \\
${\text { Available P }\left(\mathrm{mg} \mathrm{dm}^{-3}\right)^{2}}_{\mathrm{Ca}^{2+}\left(\mathrm{mmol}_{\mathrm{c}} \mathrm{dm}^{-3}\right)^{3}}$ & 52.8 \\
$\mathrm{Mg}^{2+}\left(\mathrm{mmol}_{\mathrm{c}} \mathrm{dm}^{-3}\right)^{3}$ & 178.5 \\
$\mathrm{~K}^{+}\left(\mathrm{mmol}_{\mathrm{c}} \mathrm{dm}^{-3}\right)^{4}$ & 127.3 \\
$\mathrm{Na}^{+}\left(\mathrm{mmol}_{\mathrm{c}} \mathrm{dm}^{-3}\right)^{4}$ & 3.8 \\
$\mathrm{SB}\left(\mathrm{mmol}_{\mathrm{c}} \mathrm{dm}^{-3}\right)^{5}$ & 6.7 \\
$\mathrm{H}+\mathrm{Al}^{3+}\left(\mathrm{mmol}_{\mathrm{c}} \mathrm{dm}^{-3}\right)^{6}$ & 316.3 \\
$\mathrm{CEC}\left(\mathrm{mmol}_{\mathrm{c}} \mathrm{dm}^{-3}\right)^{7}$ & 0 \\
$\mathrm{ESP}(\%)^{8}$ & 316.3 \\
$\mathrm{~B}\left(\mathrm{mg} \mathrm{dm}^{-3}\right)^{9}$ & 2.12 \\
$\mathrm{Cu}\left(\mathrm{mg} \mathrm{dm}^{-3}\right)^{10}$ & 0.69 \\
$\left.\mathrm{Fe} \mathrm{(mg} \mathrm{dm})^{-3}\right)^{10}$ & 1.9 \\
$\mathrm{Mn}\left(\mathrm{mg} \mathrm{dm}^{-3}\right)^{10}$ & 22 \\
$\mathrm{Zn}\left(\mathrm{mg} \mathrm{dm}^{-3}\right)^{10}$ & 20.2 \\
\hline
\end{tabular}

${ }^{1} \mathrm{OM}=1.724 \times 0 \mathrm{C}$ (Walkley-Black); ${ }^{2}$ Method of Mehlich-1; ${ }^{3}$ Method of $1 \mathrm{~N} \mathrm{KCl} ;{ }^{4}$ Method of $0.05 \mathrm{~N} \mathrm{HCl} ;{ }^{5} \mathrm{SB}=\mathrm{Ca}^{2+}+\mathrm{Mg}^{2+}+\mathrm{K}^{+}+\mathrm{Na}^{+} ;{ }^{6}$ Method of $0.5 \mathrm{~N} \mathrm{Ca}(0 \mathrm{Ac}) 2, \mathrm{pH} 7 ;{ }^{7} \mathrm{CEC}=\mathrm{SB}$ $+\left(\mathrm{H}+\mathrm{Al}^{3+}\right) ;{ }^{8} \mathrm{ESP}=(\mathrm{Na} / \mathrm{CEC})^{*} 100 ;{ }^{9}$ Method of hot water; ${ }^{10}$ Method of DTPA

At planting, all experimental units received basal fertilization with single superphosphate and potassium chloride in order to meet the recommendation of $40 \mathrm{~kg} \mathrm{ha}^{-1}$ of $\mathrm{P}_{2} \mathrm{O}_{5}$ and $20 \mathrm{~kg} \mathrm{ha}^{-1}$ of $\mathrm{K}_{2} \mathrm{O}$ for the crop (Cavalcanti, 2008). $\mathrm{N}$ fertilization was performed through a split application of urea ( $44 \%$ of $\mathrm{N})$; one third at planting, one third at 30 days and the rest 60 days after emergence.

Daily irrigation was performed in order to replenish the daily evaporation of the crop (ETc), calculated based on the weekly crop coefficients $(\mathrm{kc})$ determined by Azevedo et al. (1993) for medium-cycle cultivars of upland cotton in the state of Paraíba. Reference evapotranspiration (ETo) was obtained through the Penman-Monteith method, using climatic data recorded by a data logger installed in the experimental area. The weekly irrigation depths obtained in millimeters were converted to liters according to the superficial area of the pots and then divided for the application of daily irrigation, performed with the aid of graduated cylinders. The period of irrigated cultivation was equal to 123 days, with total water depth of approximately $620 \mathrm{~mm}$, which was equivalent to the volume of $95 \mathrm{~L}$ of water or effluents in each pot, according to the treatments.

After the end of the cotton cycle, soil samples were collected in each pot and subjected to chemical characterization at the laboratory. The following variables were determined: soil $\mathrm{pH}$; potential acidity $\left(\mathrm{H}^{+}+\mathrm{Al}^{3+}\right)$; organic matter content; contents of exchangeable calcium, magnesium, sodium and potassium; content of available phosphorus according to the methodology proposed by EMBRAPA (1997) and the contents of the micronutrients boron, copper, iron, manganese and zinc, according to the methodology proposed by Raij et al. (2001).

The obtained data were subjected to analysis of variance using the statistical program SISVAR. The effects of irrigation water quality were compared by Tukey test at 0.05 probability level, while the effects of $\mathrm{N}$ doses were evaluated through linear and quadratic regression analyses.

\section{Results AND Discussion}

After irrigated cultivation, the mean $\mathrm{pH}$ values of the soils that received freshwater (FW) and treated effluents (UASB, UASB+ISF and TS+ISF) were similar, ranging from 7.54 to 7.72 (Table 3 ). This behavior was possibly due to the similarity between the $\mathrm{pH}$ of the sources of water used for irrigation and is consistent with that observed by the other authors who compared the effects of irrigation with good quality water and treated wastewater in agricultural soils (Bedbabis et al., 2014).

In comparison to the initial condition, there was a slight increase in soil $\mathrm{pH}$, lower than 1 unit, similar to that 
Table 3. Means and summary of the analysis of variance for $\mathrm{pH}$ values and contents of potential acidity $\left(\mathrm{H}^{+}+\mathrm{Al}^{3+}\right)$, soil organic matter $(\mathrm{SOM})$ and exchangeable potassium $\left(\mathrm{K}^{+}\right)$, calcium $\left(\mathrm{Ca}^{2+}\right)$, magnesium $\left(\mathrm{Mg}^{2+}\right)$ and sodium $\left(\mathrm{Na}^{+}\right)$in the soil after cultivation, as a function of the tested factors

\begin{tabular}{|c|c|c|c|c|c|c|c|c|}
\hline+2 & $\begin{array}{c}\mathrm{pH} \\
\left(-\log \left[\mathrm{H}^{+}\right]\right)\end{array}$ & $\underset{\left(\mathrm{H}+\mathrm{AA}^{++}\right.}{\mathrm{mmol}^{+\mathrm{dm}^{-3}}}$ & $\begin{array}{c}\text { SOM } \\
\left(\mathrm{g} \mathrm{kg}^{-1}\right)\end{array}$ & $\begin{array}{c}\stackrel{P}{P} \\
(\mathrm{mg} \mathrm{dm}\end{array}$ & $\mathrm{K}^{+}$ & \multicolumn{2}{|c|}{$\begin{array}{lr}\mathrm{Ca}^{2+} & \mathrm{Mg}^{2+} \\
& \left(\mathrm{mmol}_{\mathrm{g}} \mathrm{dm}^{-3}\right)\end{array}$} & $\mathrm{Na}^{+}$ \\
\hline
\end{tabular}

\begin{tabular}{|c|c|c|c|c|c|c|c|c|}
\hline \multicolumn{9}{|l|}{ Sources of water } \\
\hline FW & $7.60 \mathrm{a}$ & $0.00 \mathrm{a}$ & $11.77 \mathrm{~b}$ & $132.03 \mathrm{a}$ & $1.69 \mathrm{~b}$ & $122.63 \mathrm{a}$ & $106.36 \mathrm{a}$ & $25.10 \mathrm{~b}$ \\
\hline UASB & $7.54 \mathrm{a}$ & $0.54 \mathrm{a}$ & $14.05 \mathrm{a}$ & $142.22 \mathrm{a}$ & $2.18 \mathrm{a}$ & $122.56 \mathrm{a}$ & $105.21 \mathrm{a}$ & $46.77 \mathrm{a}$ \\
\hline UASB + ISF & $7.60 \mathrm{a}$ & $0.79 \mathrm{a}$ & $12.55 a b$ & $140.64 \mathrm{a}$ & $2.16 \mathrm{a}$ & $120.68 \mathrm{a}$ & $106.44 \mathrm{a}$ & $47.05 \mathrm{a}$ \\
\hline $\mathrm{TS}+\mathrm{ISF}$ & $7.72 \mathrm{a}$ & $0.00 \mathrm{a}$ & $11.94 b$ & $144.28 \mathrm{a}$ & $2.06 \mathrm{a}$ & $122.72 \mathrm{a}$ & $105.53 \mathrm{a}$ & $43.75 \mathrm{a}$ \\
\hline \multicolumn{9}{|l|}{ Doses of $\mathrm{N}$} \\
\hline $0 \mathrm{~kg} \mathrm{ha}^{-1}$ & 7.84 & 0.00 & 13.18 & 132.18 & 2.03 & 128.78 & 102.91 & 39.56 \\
\hline $45 \mathrm{~kg} \mathrm{ha}^{-1}$ & 7.76 & 0.00 & 13.13 & 139.30 & 2.00 & 121.09 & 108.94 & 41.21 \\
\hline $90 \mathrm{~kg} \mathrm{ha}^{-1}$ & 7.60 & 0.00 & 11.51 & 136.03 & 1.83 & 119.61 & 109.46 & 40.63 \\
\hline $135 \mathrm{~kg} \mathrm{ha}^{-1}$ & 7.57 & 0.00 & 12.89 & 149.32 & 2.23 & 121.01 & 103.40 & 41.04 \\
\hline \multirow[t]{2}{*}{$180 \mathrm{~kg} \mathrm{ha}^{-1}$} & 7.30 & 1.65 & 12.16 & 142.12 & 2.02 & 120.25 & 102.21 & 40.90 \\
\hline & \multicolumn{8}{|c|}{ Mean squares } \\
\hline Sources of water (W) & $0.1132^{\mathrm{ns}}$ & $3.4623^{\text {ns }}$ & $21.5447^{\star \star}$ & $580.4464^{\text {ns }}$ & $1.0358^{\star \star}$ & $19.1882^{\mathrm{ns}}$ & $36.8710^{\text {ns }}$ & $2198.5531^{\star *}$ \\
\hline Doses of $N(N)$ & $0.6917^{\star *}$ & $3.1123^{\text {ns }}$ & $8.3735^{\text {ns }}$ & $674.1958^{\text {ns }}$ & $0.3258^{\text {ns }}$ & $225.5655^{\text {ns }}$ & $197.4709^{n s}$ & $6.8292^{\mathrm{ns}}$ \\
\hline $\mathrm{W} \times \mathrm{N}$ & $0.0389^{\text {ns }}$ & $4.8622^{\text {ns }}$ & $3.2272^{\text {ns }}$ & $200.3551^{\text {ns }}$ & $0.1267^{\mathrm{ns}}$ & $54.9910^{\text {ns }}$ & $110.6113^{\text {ns }}$ & $17.3116^{\text {ns }}$ \\
\hline CV (\%) & 2.9 & 20.6 & 16.2 & 11.9 & 19.8 & 8.9 & 10.4 & 11.1 \\
\hline
\end{tabular}

FW - Frashwater from the municipal supply system; UASB - Domestic wastewater treated in UASB reactor; UASB + ISF - Domestic wastewater treated in UASB reactor and post-treated in intermittent sand filters; TS + ISF - Domestic wastewater treated in septic tank and post-treated in intermittent sand filter. ns, ${ }^{*},{ }^{\star \star}$ Not significant and significant at 0.05 and 0.01 probability levels, respectively, by the $\mathrm{F}$ test of the analysis of variance

In each column, means followed by the same letter do not differ by Tukey test at 0.05 probability level

described by Leal et al. (2009a) and Tarchouna et al. (2010) after the practice of agricultural reuse for 16 and 23 months, respectively. Xu et al. (2010), however, found results different from the previously mentioned ones and observed reduction of 1.08 in the $\mathrm{pH}$ of a sandy clay soil subjected to irrigation with wastewater for 20 years.

These small alterations in soil $\mathrm{pH}$ as a function of the application of wastewater may be related to the addition of large doses of sulfates (Usman \& Ghallab, 2006), release of exchangeable cations during the mineralization of organic matter (Kiziloglu et al., 2008), oxidation of organic compounds and nitrification of ammonia or the leaching of basic cations (Xu et al., 2010). According to Laurenson et al. (2012), the level of the modifications in active acidity is conditioned by the initial $\mathrm{pH}$ and the buffering capacity, which is the ability of the soil to resist to fluctuations in its $\mathrm{pH}$.

The increasing doses of the $\mathrm{N}$ fertilizer, applied at planting, resulted in slight acidification of the soil after one crop cycle. Each increment of $100 \mathrm{~kg} \mathrm{ha}^{-1}$ in the $\mathrm{N}$ dose applied via urea corresponded to a reduction of approximately 0.3 unit in soil $\mathrm{pH}$ (Figure 1). Despite its low magnitude, the acidifying effect

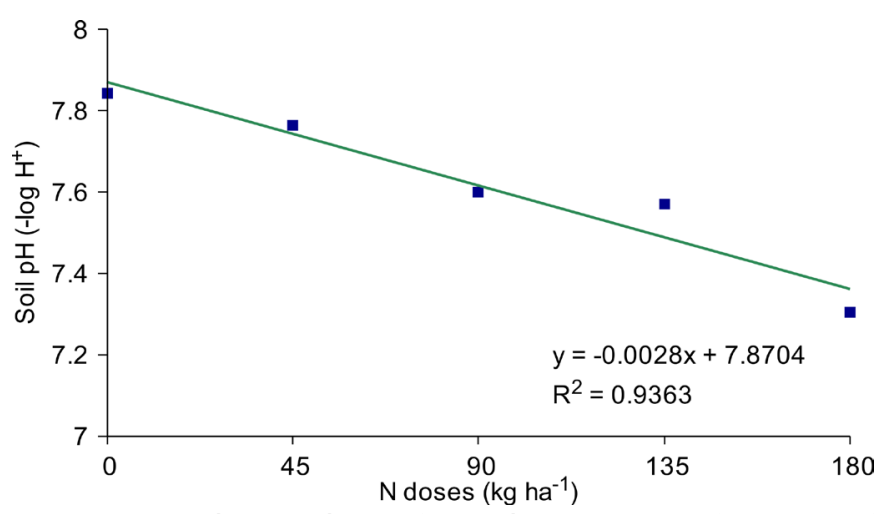

Figure 1. Soil $\mathrm{pH}$ values after cultivation as a function of nitrogen $(\mathrm{N})$ doses of the $\mathrm{N}$ fertilizer was consistent and occurred regardless of the quality of the water applied through irrigation.

Soil acidification caused by $\mathrm{N}$ fertilization is a phenomenon widely documented in the literature, even under conditions of irrigation with effluents of high $\mathrm{pH}$. Urea $\left[\mathrm{CO}\left(\mathrm{NH}_{2}\right)\right]$, when added to the soil, suffers enzymatic hydrolysis, which transforms the $\mathrm{N}$ present in the amidic form into ammonium ion $\left(\mathrm{NH}_{4}^{+}\right)$. In situations of alkaline soils, as in the present study, this compound rapidly transforms into ammonia $\left(\mathrm{NH}_{3}\right)$, which, under the action of nitrifying bacteria, is converted into nitrite $\left(\mathrm{NO}_{2}^{-}\right)$and then into nitrate $\left(\mathrm{NO}_{3}^{-}\right)$, which is readily assimilated by plants. The reaction of nitrification of $\mathrm{NH}_{3}$ has acidifying effect, since three protons $\left(\mathrm{H}^{+}\right)$are released for each mol of $\mathrm{NO}_{2}$ - formed.

Despite the alterations suffered, soil $\mathrm{pH}$ remained above 7.0 (Figure 1), which is considered by Alvarez V. et al. (1999) as very high for agriculture; however, in situations of continuous use, fertilizers can cause progressive and long-lasting reduction of $\mathrm{pH}$, which interferes with the dynamics of solubilization of ions in the soil, directly affecting their absorption by the cultivated plants.

It was not observed the presence of significant levels of exchangeable acidity $\left(\mathrm{Al}^{3+}\right)$ before or after cultivation, which was expected, since in soils with $\mathrm{pH}$ values higher than 5.5 the $\mathrm{Al}$ is found hydrolyzed and is precipitated in the form of $\mathrm{Al}(\mathrm{OH})_{3}$. Soils with $\mathrm{pH}$ above 7.0 do not have considerable amounts of $\left(\mathrm{H}^{+}\right)$protons either, which explains the low occurrence of potential acidity $\left(\mathrm{H}^{+}+\mathrm{Al}^{3+}\right)$ in the present study (Table 3).

After irrigated cultivation, there was severe reduction in the original content of soil organic matter (SOM), which dropped from 23.4 to $12.6 \mathrm{~g} \mathrm{~kg}^{-1}$, on average. However, even after cotton cultivation, the studied soil remained with SOM contents considered as very high by Alvarez V. et al. (1999).

The reduction in SOM contents was observed even in the treatments irrigated with treated wastewater, which is 
characterized by high concentrations of soluble organic matter. Other authors who observed similar effect attributed it to the high concentrations of organic $\mathrm{C}$ and $\mathrm{N}$ present in the domestic effluents, which may promote the increase of enzymatic and microbial activity of the soil, with consequent increment in SOM mineralization rates (Tarchouna et al., 2010). In addition, the alterations in an area for the adoption of an agricultural system affect the rates of SOM addition and decomposition and lead to the break of microaggregates, which may result in rapid reduction of the readily mineralizable fraction (labile) of the SOM (Zinn et al., 2005).

As to the different sources of irrigation water, the highest mean content of SOM was observed when the soil was irrigated with wastewater treated in UASB reactor, which is consistent with the higher contents of organic compounds, expressed in the form of COD, observed in this effluents. Soils that received effluents post-treated in intermittent sand filters showed SOM levels statistically similar to those observed in the treatment with water from the public supply system.

Tonetti et al. (2010) claim that the post-treatment of anaerobic effluents in intermittent sand filters is a very efficient strategy for organic matter degradation, reaching percentages of COD removal close to $99 \%$. This is a relevant factor for the success of agricultural reuse of domestic wastewater, because, although it is beneficial for the soil, the organic matter added to the medium may form chelates with the metallic nutrients, reducing their bioavailability to the cultivated plants (Qishlaqi et al., 2008). When applied in excessive amounts, effluents with high charge of organic matter can even overload the adsorption sites of the soils and be leached to deeper layers, where they may cause contamination of groundwater by soluble forms of $\mathrm{P}$ and N (Anderson \& Magdoff, 2005).

With respect to phosphorus, the treatments irrigated with sewage effluents showed $\mathrm{P}$ contents similar to those observed for the application of freshwater (Table 3). It is inferred that the $\mathrm{P}$ contents in the treated effluents were not high enough to cause considerable accumulation of the nutrient in this type of soil in a short term.

Studies conducted over a longer period and/or with effluents containing higher $\mathrm{P}$ contents, however, have reported considerable accumulations of the nutrient in the soil, notably in the subsurface layers of sandy soils (Rusan et al., 2007; Lado et al., 2012; Bame et al., 2014). The P added to the soils by the domestic sewage effluents is essentially found in the forms of orthophosphates (inorganic P) and organic phosphates (organic P), which are available to plants only after conversion to inorganic assimilable forms (Havlin et al., 2013). However, this process is slow, which leads to longer periods of residence in the soil (Anderson \& Magdoff, 2005), since $\mathrm{P}$ has high tendency to form complexes of medium and high binding energy with the solid phase of the soil, originating low-solubility compounds, while longer periods of contact may result in damages to the mobility and availability of the nutrient to plants, reflecting in higher accumulation in the soil.

In relation to the initial condition of the soil, there was an increment of about $160 \%$ in the contents of assimilable $\mathrm{P}$, which remained at levels considered by Alvarez V. et al. (1999) as very good for agriculture. The increment can be essentially attributed to the basal phosphate fertilization, because even the treatments under irrigation with supply water showed such behavior.

In comparison to the initial soil condition (Table 3), there were reductions of about 20,30 and $50 \%$ in the contents of $\mathrm{Mg}$, Ca and $\mathrm{K}$, respectively, which were probably due to the absorption of nutrients by the cultivated plants.

There were no significant differences in the contents of $\mathrm{Ca}$ and $\mathrm{Mg}$ of soils irrigated with the different sources of irrigation water (Table 3), which can be attributed to the similarity between the concentration of these nutrients in the effluents used (Table 1) or to the short time of irrigation. Leal et al. (2009a) point out that the response of soils to the application of cations through wastewater is possibly related to variations in the natural fertility of the soil, concentrations of the nutrients in the effluents and local characteristics of the production systems; more intensive systems lead to decreases and less intensive systems lead to accumulation of cations in the soil.

As to potassium, its higher contents in the soil after cultivation were related to the application of treated wastewater, probably as a result of the $\mathrm{K}$ concentrations of the treated effluents that were up to four times as high as those observed in the freshwater. Soils irrigated with domestic effluents showed mean $\mathrm{K}$ contents within the range of 1.82 to $3.07 \mathrm{mmol}_{\mathrm{c}} \mathrm{dm}^{-3}$, considered by Alvarez V. et al. (1999) as good for agricultural cultivation, and the concentration observed for the treatments under supply water was classified as "medium" by the same authors ( 1.05 to $1.79 \mathrm{mmol} \mathrm{dm}^{-3}$ ).

According to Arienzo et al. (2009), the $\mathrm{K}$ added to the soil through the disposal of wastewater has low levels of leaching, which causes the portion not absorbed by the plants to accumulate in the soil for long periods. Studies have also shown that, due to the low mobility of $\mathrm{K}$ ions in the soil, larger amounts of the element concentrate in the most superficial layers of the profile (Lado et al., 2012; Bedbabis et al., 2014).

Irrigation also increased the levels of exchangeable sodium in the soil, especially when treated effluents were used. Soils that received domestic wastewater showed mean $\mathrm{Na}$ contents up to $86 \%$ higher than those in the treatments irrigated with freshwater and $600 \%$ higher than those observed before planting (Table 4). Reports like these are very common in soils irrigated with sewage effluents (Leal et al., 2009b; Bedbabis et al., 2014), making $\mathrm{Na}$ accumulation one of the greatest concerns in areas of agricultural reuse (Muyen et al., 2011).

High $\mathrm{Na}$ contents in the exchange sites of clay minerals can be harmful to the soil, because they reduce the attraction between the mineral particles causing expansion and dispersion of clays, which may compromise the structure, alter porosity and reduce the hydraulic conductivity of the soil (Lado \& Ben-Hur, 2009). Leal et al. (2009b) observed occurrence of clay dispersion in soils irrigated with wastewater containing up to $120 \mathrm{mg} \mathrm{L}^{-1}$ of $\mathrm{Na}^{+}$. Since the $\mathrm{Na}$ concentration in the effluents used in the present study was, on average, higher than $150 \mathrm{mg} \mathrm{L}^{-1}$, the monitoring, as well as remediation of the soil after irrigation with these effluents, is of great importance to maintain the sanity and the potential for agricultural use of the irrigated area.

In comparison to irrigation with water from the public supply system, the application of treated sewage effluents 
increased the contents of boron, copper, iron, manganese and zinc in the soil by up to $33,31,17,20$ and $44 \%$, respectively (Table 4), maintaining the concentrations of these nutrients at levels considered as high for agriculture, according to Raij et al. (1996).

After irrigated cultivation, the concentrations of all evaluated microelements were, however, lower than those originally observed in the soil, indicating that irrigation with treated sewage effluents was not efficient at replenishing the micronutrients removed and/or absorbed by the crop. This fact leads to the inference that, in crops fertigated with reuse water, it is of great importance to evaluate the levels of micronutrients in the soil and in the effluent, complementing with fertilization if necessary.

Recent studies on the dynamics of micronutrients in soils irrigated with domestic wastewater have obtained inconsistent results. This can be attributed to the high fluctuation in the mobility of these elements in response to modifications in soil characteristics, to the various levels of absorption by plants and also to the different levels of extraction obtained through distinct methods of detection (Gwenzi \& Munondo, 2008).

The accumulation of micronutrients and heavy metals due to the application of wastewater can be caused directly, by the composition of the applied effluents, or indirectly, by the increase in the solubility of the metals present in insoluble forms in the native soil, as a result of the chelation or acidifying action of the waste used (Rusan et al., 2007).

Bedbabis et al. (2010) analyzed the effects of irrigation with treated effluents along 2 years in a sandy soil cultivated with olive trees in Tunisia and observed that the application of wastewater promoted greater accumulation of $\mathrm{Mn}$ and $\mathrm{Zn}$ in the soil, compared with the management with good water quality. Lado et al. (2012), however, report that soils with similar texture irrigated with secondary effluents for 7 years

Table 4. Means and summary of the analysis of variance for the micronutrients boron (B), copper $(\mathrm{Cu})$, iron $(\mathrm{Fe})$, manganese $(\mathrm{Mn})$ and zinc $(\mathrm{Zn})$ determined in the soil at the end of the experiment

\begin{tabular}{|c|c|c|c|c|c|}
\hline & B & Cu & $\mathrm{Fe}$ & Mn & $\mathrm{Zn}$ \\
\hline & \multicolumn{5}{|c|}{$\left(\mathrm{mg} \mathrm{dm}^{-3}\right)$} \\
\hline Sources of water & \multicolumn{5}{|c|}{ Mean values } \\
\hline FW & $0.51 \mathrm{~b}$ & $0.88 \mathrm{~b}$ & $16.27 \mathrm{~b}$ & $13.54 b$ & $1.03 b$ \\
\hline UASB & $0.68 \mathrm{a}$ & $1.15 \mathrm{a}$ & $19.12 \mathrm{a}$ & $16.29 \mathrm{a}$ & $1.48 \mathrm{a}$ \\
\hline UASB + ISF & $0.55 b$ & $1.00 \mathrm{ab}$ & $17.27 \mathrm{ab}$ & $16.18 \mathrm{a}$ & $1.16 a b$ \\
\hline $\mathrm{TS}+\mathrm{ISF}$ & $0.59 \mathrm{ab}$ & $1.06 \mathrm{a}$ & $17.87 \mathrm{ab}$ & $16.53 \mathrm{a}$ & $1.23 a b$ \\
\hline \multicolumn{6}{|l|}{ Doses of $\mathrm{N}$} \\
\hline $0 \mathrm{~kg} \mathrm{ha}^{-1}$ & 0.60 & 1.02 & 16.58 & 13.83 & 1.35 \\
\hline $45 \mathrm{~kg} \mathrm{ha}^{-1}$ & 0.55 & 1.02 & 17.27 & 14.43 & 1.24 \\
\hline $90 \mathrm{~kg} \mathrm{ha}^{-1}$ & 0.54 & 0.96 & 16.75 & 15.46 & 1.14 \\
\hline $135 \mathrm{~kg} \mathrm{ha}^{-1}$ & 0.62 & 1.06 & 18.27 & 15.93 & 1.35 \\
\hline $180 \mathrm{~kg} \mathrm{ha}^{-1}$ & 0.61 & 1.06 & 19.27 & 18.51 & 1.05 \\
\hline Factors & \multicolumn{5}{|c|}{ Mean squares } \\
\hline Sources of water (W) & $0.1018^{\star \star}$ & $0.2652^{* *}$ & $28.3792^{*}$ & $39.5318^{\star *}$ & $0.7388^{*}$ \\
\hline Doses of $N(N)$ & $0.0213^{\text {ns }}$ & $0.0267^{\text {ns }}$ & $20.4062^{\text {ns }}$ & $52.4724^{* *}$ & $0.2817^{\mathrm{ns}}$ \\
\hline $\mathrm{W} \times \mathrm{N}$ & $0.0088^{\text {ns }}$ & $0.0263^{\text {ns }}$ & $7.2038^{\mathrm{ns}}$ & $8.6047^{\mathrm{ns}}$ & $0.3132^{\mathrm{ns}}$ \\
\hline CV (\%) & 19.8 & 19.8 & 16.6 & 16.9 & 36.1 \\
\hline
\end{tabular}

FW - Frashwater from the municipal supply system; UASB - Domestic wastewater treated in UASB reactor; UASB + ISF - Domestic wastewater treated in UASB reactor and post-treated in intermittent sand filters; TS + ISF - Domestic wastewater treated in septic tank and post-treated in intermittent sand filter. In each column, means followed by the same letter do not differ by Tukey test at 0.05 probability level; ns, * ${ }^{* *}$ Respectivelly not significant and significant at 0.05 and 0.01 probability level by the $F$ test of the analysis of variance showed lower Fe contents and $\mathrm{Cu}$ and $\mathrm{Zn}$ contents similar to those observed under the application of freshwater.

As to boron, most studies that mention its dynamics in areas of reuse have reported the increase in its contents in the soil resulting from the application of sewage effluents (Lado et al., 2012). According to Ben-Hur (2004), B sources in domestic wastewater include human feces, household detergents and powdered soap. The authors also claim that the $\mathrm{B}$ removal rates by biological treatments methods, such as UASB reactors and septic tanks, are very low. This can be the justification for the higher contents of B observed in soils irrigated with wastewater treated only in UASB reactor, in relation to those receiving effluents subjected to one step of post-treatment with sand filters. The greater removal of B is a positive aspect in the production of effluents intended for the reuse in agriculture, because the high B accumulation in the superficial layers of soils irrigated with treated effluents can be toxic to some sensitive crops.

As mentioned by Rusan et al. (2007), the poor management of irrigation with wastewater, especially under long-term applications, may lead to problems of toxicity by heavy metals and high accumulation of nutrients, with deterioration of soil characteristics and quality of the cultivated products.

With respect to mineral $\mathrm{N}$ fertilization (Figure 2), each increment of $100 \mathrm{~kg} \mathrm{ha}^{-1}$ in the $\mathrm{N}$ dose caused increase of $2.42 \mathrm{mg} \mathrm{dm}^{-3}$ in the mean content of $\mathrm{Mn}$ of the soils irrigated with different types of irrigation water. This result is probably related to the reduction of soil $\mathrm{pH}$ observed as a consequence of $\mathrm{N}$ fertilization.

As claimed by Havlin et al. (2013), each increment of 1 unit in soil $\mathrm{pH}$ reduces by 100 times the concentration of the main form of $\mathrm{Mn}$ in solution $\left(\mathrm{Mn}^{2+}\right)$. The authors claim that the low availability of $\mathrm{Mn}$, usually observed in calcareous soils or soils with high $\mathrm{pH}$, can be completely overcome by acidification, which promotes the solubilization of organic complexes and other poorly-available forms of $\mathrm{Mn}$.

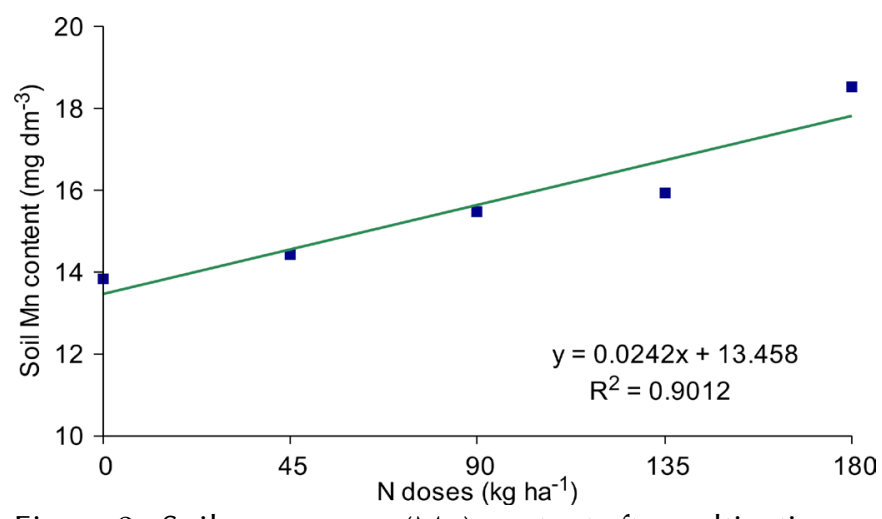

Figure 2. Soil manganese $(\mathrm{Mn})$ content after cultivation as a function of nitrogen $(\mathrm{N})$ doses

\section{Conclusions}

1. Irrigation with wastewater promotes greater accumulation of micronutrients and potassium in the soil, compared with conventional management with freshwater.

2. The use of treated sewage effluents in fertigation leads to increase in the contents of exchangeable sodium in the soil. 
3. High doses of nitrogen fertilizer reduce soil $\mathrm{pH}$ and may cause increase in manganese contents in the soil.

\section{Literature Cited}

Alvarez V., V. H.; Novais, R. F.; Barros, N. F.; Cantarutti, R. B.; Lopes, A. S. Interpretação dos resultados das análises de solos. In: Ribeiro, A. C.; Guimarães, P. T. G.; Alvarez V., V. H. 1999. Recomendações para o uso de corretivos e fertilizantes em Minas Gerais $-5^{\circ}$ Aproximação. Viçosa: UFV, 1999. Cap.5, p.25-32.

Anderson, B. H.; Magdoff, F. R. Relative movement and soil fixation of soluble organic and inorganic phosphorus. Journal of Environmental Quality, v.34, p.2228-2233, 2005. http://dx.doi. org/10.2134/jeq2005.0025

Arienzo, M.; Christen, E. W.; Quayle, W.; Kumar, A. A review of the fate of potassium in the soil-plant system after land application of wastewaters. Journal of Hazardous Materials, v.164, p.415-422, 2009. http://dx.doi.org/10.1016/j.jhazmat.2008.08.095

Azevedo, P. V. de; Ramana Rao, T. V.; Amorim Neto, M. S.; Bezerra, J. R. C; Espínola Sobrinho, J.; Maciel, G. F. Necessidades hídricas da cultura do algodoeiro. Pesquisa Agropecuária Brasileira, v.28, p.863-870, 1993.

Bame, I. B.; Hughes, J. C.; Titshall, L. W.; Buckley, C. A. The effect of irrigation with anaerobic baffled reactor effluent on nutrient availability, soil properties and maize growth. Agricultural Water Management, v.134, p.50-59, 2014. http://dx.doi.org/10.1016/j. agwat.2013.11.011

Bedbabis, S.; Ferrara, G.; Rouina, B. B.; Boukhris, M. Effects of irrigation with treated wastewater on olive tree growth, yield and leaf mineral elements at short term. Scientia Horticulturae, v.126, p.345-350, 2010. http://dx.doi.org/10.1016/j.scienta.2010.07.020

Bedbabis, S.; Rouina, B. B.; Boukhris, M.; Ferrara, G. Effect of irrigation with treated wastewater on soil chemical properties and infiltration rate. Journal of Environmental Management, v.133, p.45-50, 2014. http://dx.doi.org/10.1016/j.jenvman.2013.11.007

Ben-Hur, M. Sewage water treatments and reuse in Israel. In: Zereini, F.; Jaeschke, W. (ed.) Water in the middle east and in North Africa. Heidelberg: Springer-Verlag, 2004. p.167-180. http://dx.doi. org/10.1007/978-3-662-10866-6_15

Cavalcanti, F. J. A. (coord.). Recomendações de adubação para o estado de Pernambuco: 2a aproximação. 2.ed. Recife: IPA, 2008. $212 p$.

EMBRAPA - Empresa Brasileira de Pesquisa Agropecuária. Centro Nacional de Pesquisa de Solos. Manual de métodos de análise do solo. 2.ed. Rio de Janeiro: Embrapa Solos, 1997. 212p.

Gwenzi, W.; Munondo, R. Long-term impacts of pasture irrigation with treated sewage effluent on nutrient status of a sandy soil in Zimbabwe. Nutrient Cycling in Agroecosystems, v.82, p.197-207, 2008. http://dx.doi.org/10.1007/s10705-008-9181-3

Havlin, J. L.; Tisdale, S. L.; Nelson, W. L.; Beaton, J. D. Soil fertility and fertilizers. 8ed. Upper Saddle River: Prentice Hall, 2013. 528p.

Kiziloglu, F. M.; Turan, M.; Sahin, U.; Kuslu, Y.; Dursun, A. Effects of untreated and treated wastewater irrigation on some chemical properties of cauliflower (Brassica olerecea L. var. botrytis) and red cabbage (Brassica olerecea L. var. rubra) grown on calcareous soil in Turkey. Agricultural Water Management, v.95, p.716-724, 2008. http://dx.doi.org/10.1016/j.agwat.2008.01.008
Lado, M.; Bar-Tal, A.; Azenkot, A.; Assouline, S.; Ravina, I.; Erner, Y.; Fine, P.; Dasberg, S.; Ben-Hur, M. Changes in chemical properties of semiarid soils under long-term secondary treated wastewater irrigation. Soil Science Society of America Journal, v.76, p.13581369, 2012. http://dx.doi.org/10.2136/sssaj2011.0230

Lado, M.; Ben-Hur, M. Treated domestic sewage irrigation effects on soil hydraulic properties in arid and semiarid zones: A review. Soil and Tillage Research, v.106, p.152-163, 2009. http://dx.doi. org/10.1016/j.still.2009.04.011

Laurenson, S.; Bolan, N. S.; Smith, E.; McCarthy, M. Review: Use of recycled wastewater for irrigating grapevines. Australian Journal of Grape and Wine Research, v.18, p.1-10, 2012. http://dx.doi. org/10.1111/j.1755-0238.2011.00170.x

Leal, R. M. P.; Firme, L. P.; Montes, C. R.; Melfi, A. J.; Piedade, S. M. S. Soil exchangeable cations, sugarcane production and nutrient uptake after wastewater irrigation. Scientia Agricola, v.66, p.242249, 2009a. http://dx.doi.org/10.1590/S0103-90162009000200014

Leal, R. M. P.; Herpin, U.; Fonseca, A. F.; Firme, L. P.; Montes, C. R.; Melfi, A. J. Sodicity and salinity in a Brazilian Oxisol cultivated with sugarcane irrigated with wastewater. Agricultural Water Management, v.96, p.307-316, 2009b. http://dx.doi.org/10.1016/j. agwat.2008.08.009

Muyen, Z.; Moore, G. A.; Wrigley, R. J. Soil salinity and sodicity effects of wastewater irrigation in South East Australia. Agricultural Water Management, v.99, p.33-41, 2011. http://dx.doi.org/10.1016/j. agwat.2011.07.021

Pescod, M. B. Wastewater treatment and use in agriculture. In: Irrigation and Drainage Paper n.47. Rome: Food and Agriculture Organization, 1992. 125p.

Qishlaqi, A.; Moore, F.; Forghani, G. Impact of untreated wastewater irrigation on soils and crops in Shiraz suburban area, SW Iran. Environmental Monitoring and Assessment, v.141, p.257-273, 2008. http://dx.doi.org/10.1007/s10661-007-9893-x

Raij, B. van; Andrade, J. C.; Cantarella, H.; Quaggio, J. A. Análise química para avaliação da fertilidade de solos tropicais. Campinas: Instituto Agronômico, 2001. 284p.

Raij, B. van; Cantarella, H.; Quaggio, J. A.; Furlani, A. M. C. Recomendações de adubação e calagem para o Estado de São Paulo. 2.ed. Campinas: IAC, 1996. 285p.

Ribeiro, M. R. Origem e classificação dos solos afetados por sais. In: Gheyi, H. R.; Dias, N. S.; Lacerda, C. F. (ed.). Manejo da salinidade na agricultura: Estudos básicos e aplicados. Fortaleza: INCTSal, 2010. p.12-19.

Rusan, M. J. M.; Hinnawi, S.; Rousan, L. Long term effect of wastewater irrigation of forage crops on soil and plant quality parameters. Desalination, v.215, p.143-152, 2007. http://dx.doi.org/10.1016/j. desal.2006.10.032

Tarchouna, L. G.; Merdy, P.; Raynaud, M.; Pfeifer, H-R.; Lucas, Y. Effects of long-term irrigation with treated wastewater. Part I: Evolution of soil physico-chemical properties. Applied Geochemistry, v.25, p.1703-1710, 2010. http://dx.doi.org/10.1016/j. apgeochem.2010.08.018

Tonetti, A. L.; Couracci Filho, B.; Bertoncini, E. I.; Oliveira, R. A.; Stefanutti, R. Avaliação de um sistema simplificado de tratamento de esgotos visando a utilização em áreas rurais. Revista Brasileira de Engenharia Agrícola e Ambiental, v.14, p.227-234, 2010. http:// dx.doi.org/10.1590/S1415-43662010000200015

Usman, A. R. A.; Ghallab, A. Heavy-metal fractionation and distribution in soil profiles short-term-irrigated with sewage wastewater. Chemistry and Ecology, v.22, p.267-278, 2006. http:// dx.doi.org/10.1080/02757540600812859 
Xu, J.; Wu, L.; Chang, A. C.; Zhang, Y. Impact of long-term reclaimed wastewater irrigation on agricultural soils: A preliminary assessment. Journal of Hazardous Materials, v.183, p.780-786, 2010. http://dx.doi.org/10.1016/j.jhazmat.2010.07.094
Zinn, Y. L.; Lal, R.; Resck, D. V. S. Changes in soil organic carbon stocks under agriculture in Brazil. Soil and Tillage Research, v.84, p.28-40, 2005. http://dx.doi.org/10.1016/j. still.2004.08.007 